\title{
Justification of Judicial Decisions ${ }^{\dagger}$
}

\author{
Samuel I. Shuman*
}

It would not be much of an exaggeration to say that at least in the English-speaking world, and in much of the Western world, almost all contemporary legal philosopliy is written under the shadow of Hans Kelsen. I say "shadow" because only in the very recent past have serious analytical efforts been made to slow some of the inadequacies or distortions in the Kelsenian architectonics. His early work on the structure of a legal system cast such a strong light that for decades it would have been more accurate to say that almost all serious work in Western legal philosophy was done under the Kelseman sun. Although it lias been 20 years, it is still easy to recall the almost traumatic reaction to my reading Kelsen for the first time. Kant, Hegel, Kohler, Stammler, and other of his philosoplic predecessors all seemed so much less modern than Kelsen, so unuch less concerned with the crucial, contemporary issues.

What is somewhat surprising about the work of Kelsen and, in fact, about the legal positivists generally, has been their neglect of the judicial process. Kelsen, Austin, and Hart lave done such brilliant work in focusing attention upon the complexities of the kind of structure that characterizes a legal system that it is perliaps ungenerous also to have expected them to appreciate more fully the subtleties of the way the judicial process affects that structure. Their concentration upon the structure of a legal system and their central concern with legitimacy, rather than with the continuity of a legal system, is somewhat understandable, since all of them wrote against the background of rather stable legal institutions and not out of a need to deal with the problem of revolutionary legitimacy. In this connection it is interesting to observe that although Kelsen (as well as Austin and Hart) has never been relied upon by the highest courts in England or America for any purpose, Kelsen has been used, abused, ${ }^{1}$ relied upon, and cited in a number

$\dagger$ This Article is adapted from the author's forthcoming book, tentatively entitled Philosophical Jurisprudence: An Introduction to Some of the Problems, to be published in 1972.

* Professor of Law and Psychiatry, Wayne State University. A.B. 1947, A.M. 1948, Ph.D. 1951, University of Pennsylvania; J.D. 1954, University of Michigan; S.J.D. 1959, Harvard University.

1. See A. Ehrenzweig, Legal Phlosophy from Plato to Fredd and After $\S 12(1971)$. 
of cases where a revolutionary situation created a crisis of legitimacy and when the courts were asked to suppress the problem. The South African constitutional cases ${ }^{2}$ are an excellent example, although Pakis$\tan ^{3}{ }^{3}$ Cyprus, ${ }^{4}$ and more recently Uganda, ${ }^{5}$ as well as other countries ${ }^{8}$ have made important contributions to the growing hiterature on how to use the judicial process to minimize the adverse consequences of an openly political solution to political problems. In these cases, Kelsen's rehance upon efficacy as a criterion for legitimacy ${ }^{7}$ is seized upon, which when added to some non-Kelsenian theories about "state necessity," 8 provides an almost sure cure for any legitimacy crisis.

In part because legal positivists have largely ignored the problems of the judicial process and the question of low judicial decisions are justified, and in part because some of the best contemporary jurisprudential literature focuses attention on those questions, I have chosen to contribute to this special Kelsen issue by offering a few comments upon those problems as dealt with in the current literature.

\section{I}

\section{THE NEED FOR JUSTIFICATION}

Almost all people over 30 , and most who are under 30 as well, are still under tlie influence of the pre-hippie philosophy that deliberation and reason are better than spontaneous love as a method for solving important problems. Consequently, most people like to think that their important decisions are not made whimsically. In deciding whether to marry, to liave children, to change jobs, to engage in criminal, civilly disobedient conduct, and $\mathrm{m}$ other cases where the conduct and even lifestyle affected by the decision is likely to be irreversible or at least highly durable, most continue to beheve that a deliberate decision is better than one that is whimsical, irrational, capricious, opaque, or reckless. Why people believe this, or whether there is convincing sociological or psychological evidence that deliberation produces better

2. Harris v. Minister of the Interior, [1952] 2 S. Afr. L.R. 428 (S. Afr. App. Div.); Minister of the Interior v. Harris, [1952] 4 S. Afr. L.R. 769 (S. Afr. App. Div.); Collins v. Minister of the Interior, [1957] 1 S. Afr. L.R. 552 (S. Afr. App. Div.).

3. E.g., State v. Dosso, [1958] 1 P.L.D. Pak. S. Ct. 533, 539-40 (citing Kelsen).

4. Attorney General v. Ibrahim, [1964] Cyprus L.R. 195.

5. E.g., Uganda v. Commissioner of Prisons ex parte Matovu, [1966] E. Afr. L.R. 514, 535-37 (citing Kelsen).

6. E.g., Madzimbamuto v. Lardner-Burke, [1968] 2 S. Afr. L.R. 284, 315-17 (Rhodesia) (citing Kelsen), rev'd, [1969] 1 A.C. 645 (P.C. 1968).

7. H. Kelsen, PURe Theory of LAw 208-14 (1967).

8. See Attorney General v. Ibrahin, [1964] Cyprus L.R. 195, 257-65 (Josephides, J.); D. Jellinek, Gesetz und Verodnung 376 (1887); 1 R. Odent, ContenTIEUX ADMMNSTRATIF 136-38 (1958); Williains, The Defense of Necessity, 6 CURRENT Legal Prob. 216, 225-31 (1953). 
results than whimsey, or what "better" means in this context, is not very important. What is important is that most people have a strong preference for dehberation, especially in cases where someone else makes a decision that will seriously affect them. In law, this preference manifests itself strongly in the insistence that judicial decision be rationally justified. It would be extraordinary were we not to demand justification since now, more than ever, law is not an accidental, haphazard, occasional intrusion into our lives, but rather a constant, pervasive, frequently decisive, and almost always relevant factor affecting our very right to existence, let alone the quality of that existence.

Any clarification of the justification concept must begin by recognizing that the judicial inethod of conflict resolution is a paradigm of institutionalized deliberation, and that alternatives to this method, in varying degrees and ways, are likely to be whimsical, irrational, capricious, opaque, or reckless. ${ }^{9}$ Particularly is this so in connection with one of our most deeply entrenched perceptions about justice, at least preanalytically, if not also subsequently: namely, the expectation that equals will be treated equally. Where uniformity is a goal, any nondeliberate procedure would produce uniformity only by accident. Justice conceived as the equal treatment of equals would be unattainable where the dispute resolution technique is by combat, tossing coins, rolling dice, mquisition, cadi, weighing the documents, or staying longer under water. In varying degrees, each of these techniques suffers from soine of the defects we have been speaking of, and most suffer all the defects together. Not that all cadi justice need be whimsical or necessarily reckless, nor need an inquisition or trial by torture be opaque. But the chances that each of these methods will suffer one or all of these defects is regularly, systematically, and even normally so great that there is a rational basis for favoring the judicial method when there is a preference for dehberate, uniform decisions. Hence, part of what is meant by justification of a judicial decision is that the decision be shown to have fulfilled our expectations of dehiberation and uniformity which led to our favoring the judicial method of conflict resolution in the first place.

\section{II}

\section{The Doctrine of Stare Decisis}

What it means for judicial decisions to be deliberate or uniform is hardly obvious, but so far as both expectations are concerned, the coin-

9. In the longer chapters from which this selection is taken, I am concerned with what we mean when we ask for justification of a judicial decision. In this abridgement, I must limit discussion to only two of the several features usually associated with justification. Furthermore, the discussion here does not apply to the special case of the 
mitment to account for precedents plays a crucial role. It is not just any doctrine of precedent that is relevant, but rather in judicial decisionmaking, it is the doctrine called stare decisis.

One of the first features of this doctrine that needs be noticed is that, unlike mechanical rules of precedent mechanically applied, no single standard is expected to determine a case even though this doctrine of precedent is relied upon. This is so because no one rule or even one ratio decidendi is logically necessary for a given judicial decision. In view of this state of affairs numerous writers, especially the legal realists, have called upon the profession and the public to acknowledge that whatever uniformity there is among judicial decisions is not due to some logical restraint exercised by a commitment to the doctrine of stare decisis, but due rather to the training of judges, their emotional commitment to the fairness of treating equals equally, and so on. Rolf Sartorious has made one of the most interesting efforts to salvage the doctrine from the fate of having been demoted all the way from a logical restraint down to a mere attitude. He argues that it is neither the rule announced in the precedent case nor its ratio that is binding, but "simply the decisions themselves . . . which are logically binding, and which later courts must therefore stand by. . . . Rather than being obligated to fit his decision into a matrix of extant common law rules, the judge . . . is merely bound to reaclı a decision which, along with prior decisions, can be fitted into a matrix of rules which he himself is in large part free to construct." ${ }^{.10}$

Although this is a logically interesting move in the effort to save the doctrine of stare decisis from falling into the catch-all category of those "merely" psycliological or social pressures that act upon the judge, the allegedly logical character of the obligation under this formulation is rather difficult to appreciate. If all that courts need "stand by" and all that is "logically binding" are prior decisions, then either no two decisions are ever inconsistent (because the parties, time, etc. are different) or all decisions for the plaintiff are inconsistent with all decisions for the defendant. As Sartorius himself carefully points out, ${ }^{11}$ a decision is distinguished from the judge's opinion and from the rules or principles to which the judge appeals in justifying his opinion. Since it is decisions, and not rules or ratios that judges must stand by, it is crucial to

Supreme Court, which, because of its institutional design, function, and tradition, is unlike any other court and therefore not subject to the same doctrine of stare decisis discussed here.

10. Sartorious, The Doctrine of Precedent and the Problem of Relevance, 53 ARCHIV FÜR RECHTS UND SOZIALPHILOSOPHIE 343, 355 (1967). See generally E. LEvi, AN INTRODUCTION TO LEGAL REASONING (1949).

11. Sartorious, supra note 10, at 344. 
understand what it means to "stand by" or be logically bound by a prior decision. How does a later judge not stand by a prior decision?

Sartorius defines a decision as the "ultimate conclusion of a court of law on an issuc of law raised before it."12 Hence, for him the decision or judgment is not merely an announcement of the winning party or of the extent of the loser's hability: had he meant only this then, as pointed out above, either no two decisions would ever be inconsistent or all decisions for a plaintiff would be inconsistent with all those for the defendant. But in order to avoid this logically objectionable and philosophically uninteresting consequence of his formulation of the doctrine of stare decisis, Sartorius brings back through his definition of "decision" all the old problems. Now instead of trying to discover the rule of law that determined a case or the logically necessary ratio, we rather need try to discover the court's "conclusion" or an issue of lawindeed, its "ultimate conclusion." The demand for an ultimate conclusion on an issue of law is no less opaque than the comparable demands, already so well deinolished, ${ }^{13}$ for the rule or the ratio. At bottoin, what is the difference in this context between a conclusion, an ultimate conclusion on an issue of law, and a rule covering that same issue of law? Is there some critical feature buried in the undeveloped notion of "issue" so that there are conclusions about issues but rules about something else?

Suppose the issue before the court is whether an oral promise to make a particular testamentary disposition should be enforced. The plaintiff alleges that the decedent promised to will him a certain house if the plaintiff cared for the decedent in his old age. There is no relevant statute on the oral promise issue and in all prior cases the issue was decided against the plaintiff, either because he failed to prove the promise or because there was successful challenge on the question of whether plaintiff provided the requisite care. One plausible way of understanding a difference between conclusions and rules would be the rather natural route of saying that in each of the prior cases, the court found that the evidence tendered by the plaintiff did not prove the oral promise or the performance of the requisite service. But the rule, which turns upon that conclusion, may be that an unproven oral promise will not be enforced. However, if this is what is meant by a conclusion or an ultimate conclusion on an issue of law, then the doctrine of stare decisis, requiring only consistency of conclusions, has been rendered into less than a psychological triviality. Conclusions, in the sense here identified, are never logically inconsistent: the evidence is always different.

12. Id.

13. See, e.g., F. Cohen, Ethical Systems and Legal IDeals 35 (1933); K. Llewellyn, Some Realism About Realism, 44 HARv. L. REv. 1222, 1241 (1931), in JURISPRUDENCE 42, 60 (1962). 
Perhaps we must expand the notion of a conclusion on an issue of law to save this theory of stare decisis from triviality. Now we might want to say that whether the plaintiff is deemed to have carried the burden of proof on the question of whether the promise was made is not an ultimate conclusion on an issue of law, but merely a finding on a question of fact. The conclusion on the issue of law is that because he did not carry the burden, he cannot now frustrate the testator's intentions as revealed im the will. On this interpretation, a judge does not stand by a prior decision if in a subsequent case he holds that although the plaintiff fails to carry the burden, he may nevertheless upset the testamentary disposition. The judge in the later case did not stand by the conclusion of the earlier case because the two conclusions cannot be justified within the same inatrix of rules. But this becomes suspiciously like the old rule- or ratio-centered theories of stare decisis.

Perhaps the notion of a conclusion on an issue of law need be expanded in a different way. Now it is taken to mean the rule, principle, or policy that the court decides to apply for the resolution of the controversy. For example, the court may conclude that an oral promise, whether or not proven, is not a basis for setting aside a will. But this is not logically different from the usual rule-ratio formulation of stare decisis, except that it seems to make the concern for rules, principles, and policies once removed. I see no way to avoid the conclusion: If decisions are conclusions on issues of law, and stare decisis compels that prior conclusions be binding in like cases, then either no prior decisions are logically binding or we have the old problem of the rule-ratio formulation; just as there is no one, unique rule or ratio to be derived from a prior case, neither is there a single ultimate conclusion on an issue of law.

This rather lengthy concern with the purportedly logical obligation thought to be imposed by stare decisis was pursued in order to show how tenacious is even the contemporary remnant of the old delusion that judicial decisionmaking is some kind of deductive system. In reality, the consistency called for by stare decisis is not determined by examining any two decisions, but only by considering decisions within the context of the whole system. There may be important systematic features relevant for the justification of a judicial decision, and among these an important consideration is how well the decision fits into the system and what it does when fitted in. But this is not the same as saying that prior decisions, or the rule or ratio of those decisions, are logically binding. The following is a more appropriate formulation of stare decisis: In any case where the court believes or counsel argue that some relevant rule, principle, or policy is supported by a prior case, then the respect owed the prior decision obligates the court to account for that 
rule, principle, or policy in its decision. But it is misleading to characterize this obligation as logical or moral, for it is institutional.

To say that the obligation is logical is misleading for the reasons already canvassed. Use of the term "logical" here seems to be a case where the adjective is used for its emotionally evocative power, rather than for its semantic properties. By saying that stare decisis creates a logical obligation is meant only that the obligation is important, that failure to satisfy this obligation has serious consequences. Calling the obligation of stare decisis moral is misleading for a different reason. There may be an important moral obligation incumbent upon those who agree to serve as judges to perform the judge's role in the way expected. But to say that stare decisis creates a moral obligation is only an awkward way of insisting that the expected way of judging includes giving respect to prior decisions.

I find it more accurate to characterize the obligation created by the demand for stare decisis as institutional. That is, the legal system as an institution favors a policy of judicial (as distinguished from legislative or executive) conservatisin. The policy finds life in rules and primciples that reflect a presumption in favor of the status quo when a judge pursues the proper method of judicial decision. This presumption, in turn, is given effect by the doctrine of stare decisis in that judges who play their role the way they slould will give respect to prior decisions. Giving respect to or standing by prior decisions as obligated by stare decisis does not tell the judge how to decide a future case. Rather, it tells him and those who will assess his performance that whatever decision he reaclies, he must account for all arguably relevant rules, principles, and policies announced im prior cases.

What will count as an accounting is hardly obvious. If the court in the imstant case applies the rule, principle, or policy in question, it is fairly easy to say that the court accounted for it. ${ }^{14}$ It is equally easy to characterize those cases where the court specifically overrules the prior case and refuses to apply the rule there announced. But between these polar extremes lie the more difficult cases, where courts qualify, refine, distinguish, or erode prior decisions and the rules, principles, and policies they seemingly support. Still more difficult are the cases where there seems to be a deliberate failure to account for a precedential rule, principle, or policy that a consensus of competent professionals would regard as relevant. But the fact tliat the accounting question is often difficult warrants neither the inference that there is no obligation created by the doctrine of stare decisis nor that the obligation is merely moral.

14. It does not automatically follow (although I do believe there is a connection) that if the court reached its decision in the proper inanner and accounted for the relevant rules, principles, and policies, it therefore decided wisely, justly, or even adequately. 
In suggesting that we characterize the obligation of stare decisis as institutional, I am not trying to say that the judicial method of conflict resolution rests upon a decisional process that, because of stare decisis, is sui generis. Rather, in this context the general moral obligation to do what is legitimately expected requires the deliberate and deliberating judge, in thinking rationally about the case before him, to follow a certaim pattern, a certain dcsign. The design or "map"15 he slould follow in working his way through the case is institutional because it comes with the job specifications: the judge is not a free artist. The failure to appreciate this helps account for the oversimplification and exaggeration of legal realism: the question is not merely what motivates a judge to do his job, but rather what does a judge do when he does his job. When doing their job properly, at least so far as concerns the obligation of stare decisis, judges use the design provided by like prior cases that will accommodate the instant one. The requirenent of stare decisis, that courts stand by decided cases, is the application of the general expectation of uniformity in the procedure for judicial decisionmaking. This precedent-respecting procedure tries to enhance uniformity by demanding that the same standard of decision be applied in each case to determine the legal consequence of particular action or inaction, and that the saine facts be treated as relevant in determining whether the standard is met. Thus stare decisis does not require that later courts follow earlier ones in using the same rule, ratio, or ultimate conclusion in like cases, but only that the same standards be used, and that the same category of facts be considered in deciding whether a standard is met.

Unfortunately there is not space here to consider the effect of judicial discretion upon the operation of stare decisis. But the important point is that the above formulation need not be abandoned even though a deliberate judicial decision that gives proper respect to precedent may have to justify which standard is being applied. Except for the easiest, most mechanical cases, there are typically coinpeting standards demanding application, but all that stare decisis requires is that the standard applied and the facts treated as relevant be the same as those consulted in like prior cases that are regarded as authoritative in the jurisdiction. Therefore, justifying the standard applied or the relevance of certain facts is done by showing low rules, principles, and policies dictate, warrant, support, or suggest the use of that standard and those facts. If $A$ and $B$ are competing standards supported by authoritative precedents, and the court here applies $A$ rather than $B$, the justification for its action will be unconvincing unless it can show that the case

15. See Dickinson, Legal Rules: Their Function in the Process of Decision, 79 U. PA. L. REV. 833, 849 (1931). 
announcing $A$ is more like the instant case than is the case supporting $B$. The requirement of stare decisis will have been met so long as the court followed the map, the institutional design, rather than creating as a free artist. The problem is aggravated because often a free, creative judge does so much better in solving human problems than does the judge who simply follows prior cases blindly that there is a tendency to read permissible or inevitable discretion as license for creation. But that is a subject for another time.

\section{III}

\section{Rules, Principles, ANd Policies}

It is necessary to recognize that rules, principles, and policies function differently, both as to their appropriateness and as to their relative weight, in justifying judicial decisions. For example, while there are some firm criteria for ascertaining appropriateness of rules, and perhaps even of policies and principles, there are very few criteria for ascertaining relative weight either intra se (for example, rules to rules) or inter se (for exainple, rules to policies). The appropriateness of a rule, though not its relevance, may be determined by examining how the rule was made-for example, by the proper authorities and according to the correct procedures. Primciples, on the other hand, are not so much made as grown, and policies are both made and grown, depending on the circumstances. But even when policies are formally made, the question of their appropriateness as a source of standards for judicial decisions may not be answerable save in terms of how the policy was made. ${ }^{16}$

The situation may be clarified if it is seen that justification of a judicial decision entails showing that the claims to which the parties were entitled have been satisfied. Making such a showing requires relating their claims to the standards that are relied upon in support of the decision. Saying that the parties have legitimate claims, that they are entitled to something, is to say that there are standards relevant to the resolution of their controversy. ${ }^{17}$ Justification in this context therefore requires showing which standards are relied upon in disposing of conflicting claims. At least in part, what marks off easy cases from hard ones is that in the latter the conflicting claims may be equally supported by the same legal standard. For example, suppose a landowner

16. Suggesting that appropriateness in this context is, like validity, determined by "pedigree" [see Dworkin, The Model of Rules, in LAW, REASON, AND JUSTICE 3, 7 (G. Huglies ed. 1969)], nnay be soinewliat misleading, since even though limited to rules, there may seein to be more to appropriateness than due enactment.

17. By no means are all controversies standard-related; but all those controversies where the judicial method of conflict resolution is invoked are. 
claims that his property rights are being infringed, contrary to the general principle requiring their protection, because noxious fumes or noise from adjacent property prevents the full enjoyment of his land. His neighbor claims, pursuant to the same general principle, that his enjoyment would be diminished if he were prevented from using his land as he wished. Here both claims are derived from the same general principle; $m$ the absence of what is regarded as a dispositive rule, resolution of the conflict will require appeal to standards derived from other policies and principles. Justification of the decision will therefore include judgments on the absence of a dispositive rule and on the appropriateness and relative weights of the subsidiary policies and principles relied upon. For a case such as this, which is at a rather low level of political or constitutional philosophy, the policies that support the principles relied upon will typically be presumed and left unstated. Thus in the above land dispute, a resolution in favor of the defendant may be based largely on the standard extractable from the principle that what is not prohibitcd is permitted. But the policy supporting this principle and its application here will almost invariably be left unstated, and it will surface only if the judgment is later assessed for justification. Then the policy in favor of laissez faire government may be cited, and it will be claimed that im a relatively stable, underpopulated, preindustrial, agricultural society, where this case arose, less government is preferred to the pattern of judicial intervention that may be warranted in an overpopulated, industrial, urban society, where the unregulated use of land could not be tolerated. Why it could not be tolerated will require introducing further policies, and sometimes even other principles.

In the easier case, where only one party's claims are supportable, there is either a dispositive rule or a dispositive standard derived from appropriate, sufficiently weighty pohicies or principles. Sometimes an easy case may be one where, as with the above land case, both claims depend upon the same general principle, but $\mathrm{m}$ the given jurisdiction some principle or policy has caused an authorized rulemaking institution to create (by enactment, if the legislature; by decision, if the court) a dispositive rule. For example, there conld be a zoning ordinance that determines the above controversy.

An even more interesting case of a similar type is that involving a claim by adverse possession. It is not the same as the prior land controversy because here both claims do not arise out of the general principle protecting property rights. When the adverse claimant first moves into possession of the land of another, he does so in violation of the latter's protectable property rights. Later, when the adverse claimant asserts his claim, he is arguing, in effect, that his open, notorious, and unlawful possession of the land in a way imconsistent with the rights of the owner has ripened into a property right that merits legal protection. 
When the controversy reaches the courts in this posture, both claims are dependent upon the same property principle, and if the principle means anything, it would seein to require that the courts protect the claim of the legal titleholder. Yet probably everywhere in the United States, and frequently elsewhere, a nest of policies and principles have been solidified by legislatures into a rule that disposes of these controversies. There are principles about not sleeping on your rights and policies about the need to protect innocent persons who deal with the apparent owner of the land, but when confronted with an adverse possession case, the courts are almost invariably not going to confront these principles or policies, but rather questions of fact which relate to the standards laid down in the rule supported by those principles and policies. For example: Was the possession open, notorious, inconsistent with the right of the owner? Did it last the requisite length of time? Where there is a relevant, appropriate (vahid) rule that is dispositive, it means that standards derived from other sources-policies, principles, or other rules -are either irrelevant, inappropriate, or insufficiently sturdy, either alone or in coinbination, to "incline"18 or "guide"19 the court into any route other than that of the dispositive rule.

One reason why such a large percentage of criminal prosecutions are closed on a guilty plea without trial is that in most of these cases there is an extremely visible, rigid, appropriate (valid) statutory rule furnishing a standard to support the claim of the state and an absence of any standards to support the claim of the defendant. Of course, there are also a host of other, less principled reasons that help to explain the high rate of guilty pleas, but while these reasons help explain that result-as bribery of the judge may explain a particular resultthey, like the bribe, do not justify. What justification there is for the high rate of guilty pleas is rather contingent upon the recognition of the fact that the coinpeting claims are not equally dependent upon relevant and appropriate standards. So long as the law continues to regard as both irrelevant and inappropriate standards derived from policies and principles that take account of the circumstances of birth, poverty, lack of education or employment, race, and other socially relevant factors, most defendants have no claims to place agaimst those based upon the rules of the criminal law; at best these defendants can hope that they will be shown kindness, mercy, or sympathy. But they have no rights, no claims, no entitlements to kindness, mercy, sympathy, or even understanding. Were this not true, there could be no easy cases in criminal law.

18. Dworkin, supra note 16 , at 30.

19. Hughes, Rules, Policy and Decision-Making, in LAw, REASON, AND JUSTICE, supra note 16, at 101, 111; see G. GoTTLIEB, THE LOGIC OF CHOICE (1968). 
This discussion about the meaning of an easy case, especially in criminal law, should make even clearer what $I$ hope was already apparent: the justification of a judicial decision is not tantamount to the justification of the rules, principles, and policies relied upon for the standards that support it. In all of the preceding discussion we have been concerned only with what it may mean to justify a judicial decision, and a number of different proposals have been presented for how one might proceed with such a justification. Were we to be concerned with the justification not of the decision, but of the rules that are relied upon, we would then need to examine the relations among the rules, principles, and policies in order to discover if the rule does advance a given policy or apply a given principle. On some such model, a fairly rational procedure for the justification of rules could be constructed. Whether there is any rational procedure for the justification of policies or principles is hardly obvious, and especially so since some important principles may find their only justification under some fairly imprecise notions of acceptance, custom, practice, or indifference. Part of what is involved in saying that a certain case is easy is the existence of a dispositive rule that the judge feels obliged to follow together with the absence of any relevant policies or principles that diminish this conviction. When there are no such policies or principles, it implies that the judge feels obliged to follow the rule regardless of its content, and not because of that content. In other words, in the absence of conflicting standards derived from policies or primciples, a relevant rule is sufficient to support the decision merely because it is appropriate-that is, valid. Illustrative, again, is the wholesale disposition of criminal cases at early morning sessions in almost any large city.

Even if there are some easy cases where a particular rule dictates a specific result, "[i]n the legal process the difficulties are compounded by virtue of the fact that premises tend to be not so much rules as principles or standards and by the correlative fact that there are commonly two or more such premises available arguably as starting points for reasoning." ${ }^{20}$ In his essay The Model of Rules, ${ }^{21}$ Dworkin is largely concerned with the complexities caused by the fact that there are competitive "premises" and that there are often not rules but "principles and standards." In an earlier article, Dworkin suggested that attention be devoted to the "differences in the sorts of reasoning appropriate to decision in terms of rules and decision in terms of other standards. These differences are not merely differences in the degree to which such other standards fail to match the model of rules, for they

20. Freund, Rationality in Judicial Decisions, in Ratronal Decision 109, 112 (Am. Soc'y for Pol. \& Legal Phil., Nomos VII, C. Friedrich ed. 1964).

21. Dworkin, supra note 16. 
have models of their own."22 I have already suggested that one crucial difference between rule reasoning and reasoning from policies or principles is that for the former, there may be easy cases, cases where establishing the relevance and appropriateness of a rule eliminates the need for judgment on weight. There are unlikely to be easy policy or principle cases which come before a court. However, once the question concerns justification for other than an easy case, it is difficult to see what logical ${ }^{23}$ difference there is between the justification function of rules, policies, or principles. This is especially so since hard cases, where there are conflicting, let alone contradictory rules, are unlikely to be resolved by another "higher" rule, but rather by fashioning a standard out of policy and principle criteria. Consequently, it seems more correct to say: "No precise distinctions can be made between rules, primciples and maxims, but the terms serve to mark differences of degree in the precision of guides to decision-making." ${ }^{24}$ Hughes then adds, "So we decide under rules but in the light of principles." 25 It seems to me that this is an unhappy addition, for it weakens, if not contradicts, the prior statement. If there is a difference between the way to decide with rules or primciples, then there would seem to be more than just a difference in the degree of precision with which they guide to a decision, and Dworkin would seein to be more nearly correct in suggesting that the "differences are not merely differences [of] degree."26 The explanation is this: For the easy case, the judge does decide under a rule-this is just what $I$ had been trying to show above; however, for the difficult case, the judge decides either under the rules, principles, and policies or in light of them-but if under them, then "under" means something different than it does for the easy case.

The failure to distinguish between rule reasoning in the easy case and the function of sucli reasoning in the difficult case, where there are appropriate, relevant standards that conflict, may also explain why Dworkin writes as follows:

Only rules dictate resnlts, come what may. . . . Principles do not work that way; they imcline a decision one way, though not conclusively, and they survive intact when they do not prevail. . . . If a judge believes that principles he is bound to recognize point in one direction and that principles pointing in the other direction, if any, are not of equal weight, then he must decide accordingly, just as he nust follow what lie believes to be a binding rule. ${ }^{27}$

22. Dworkin, Judicial Discretion, 60 J. PHII. 624, 632 (1963) (footnote omitted).

23. "The 'Iogical' behaviors of principles and policies also differ to some extent from each other." Id. at 632 n.5.

24. Hughes, supra note 19, at 111.

25. Id.

26. Dworkin, supra note 22, at 632 .

27. Dworkin, supra note 16 , at 30. 
The point is that not all rules, in every or any case, dictate results. If a rule applies, then the result is dictated-regardless of whether the doinain is housekeeping, accounting, or judicial decisionmaking. But the source of confusion lies in the failure to recognize that there is no argument about the logical tautalogy-there can be no argument-that if $a$ rule applies, the result is dictated. To be a rule is to be that kind of logical entity (I am tempted to say that kind of principle) that dictates a result if the entity does apply. Consequently, there is no muscle in the idea that only rules dictate results, which is probably also what Hughes means when he says that judges decide under rules; rather, the problem arises on the decision of what it means to say a rule applies and on the decisions of when a rule applies. My point is that in the context of a judicial decision, the meaning of "to apply" is not logically different for rules, policies, or principles. The confusions on this question are heigltened by the comparison of easy rule cases with difficult principle cases and by the unstated assumption that all rule cases are easy ones and all principle cases difficult ones. Because in the judicial method of conflict resolution there are many easy cases where it is clear that $a$ rule applies (and because it is a rule, $a$ result is dictated), Hughes, Dworkin, and others tell us that judges decide under rules or that only rules dictate results. My point is that they are not telling us anything about decisionmaking, judicial or otherwise; rather, they are calling our attention to a logical feature of wliat it means to be a rule.

The problems liere are further exacerbated by the assumption that all principle cases are difficult-that is, difficult so far as "dictating a result." But there is something misleading in stating that principles can only incline a decision and then stating that there are cases where the judge "nnust"28 decide according to certain principles. If he must decide that way then those principles did not just incline him, but rather determined $a$ result in the same manner as an applied rule. "Dictate" is just the right word, in fact. In both cases, to fulfill the obligations of his office and his role, the judge must decide, slould decide, as the rule or principle dictates, if that rule or principle applies. As indicated previously, the hard questions move around what it means "to apply," but on this I do not see that there is a logical difference between rules and principles.

Dworkin's case where the judge must decide according to certain primciples is like the easy rule case; in both there is either no relevant, appropriate conflicting rule, principle, or policy, or if there is some conflict, it is one that is easily resolved; typically this will mean that there is an accepted line of decisions that has already considered and

28. Id. 
resolved the particular conflict. It is difficult to understand just why there is such widespread behef that it is less difficult to weigh rulesupported conflicting claims than claims supported by conflicting principles. But this belief probably accounts for the view that principles only incline even if applied, whereas applied rules dictate. Or perhaps the difficulty stems from confusion about relevancy and the mistaken idea that a relevant rule dictates but a relevant principle only inclines. Both sides of that idea are wrong: first, not any relevant rule dictates the decision, but only the relevant applied rule; second, there may be relevant, applied principles that do dictate.

Just as there may be relevant principles that are not apphed, so too there may be unapplied relevant rules, which renders misleading Dworkin's suggestion that rules and principles differ in their survival value. When he writes that principles "survive imtact when they do not prevail,"29 he seems to be suggesting that rules do not so survive when they do not prevail. If the sentence were instead that relevant, appropriate applied principles survive intact when the result is inconsistent with what that principle dictates, but that rules do not so survive, that would be interesting, but wrong. Both rules and principles may survive intact even though they do not prevail; neither survives intact if they apply but the result is inconsistent with them. The difference is rather that a result inconsistent with an applicable principle does not raise any question about he continued validity of that principle: this is because principles are neither valid nor invalid to begin with. A result inconsistent with an applicable rule, on the other hand, raises precisely the question of continued validity. Typically, principles decay or erode, rather than being "torpedoed," as Dworkin points out; ${ }^{30}$ however, primciples may be destroyed and rules may decay or erode, as for example when they, although relevant, are regularly not applied.

There is something instructive to be gained from recognizing that principles typically lose their status as good reasons through decay rather than destruction, while for rules it is typically the opposite. What we learn is something about how principles and rules each acquire their status as candidates to justify judicial decisions: rules are made (by legislatures, courts, etc.) but principles are not; they grow. Pound put it this way:

[S] uppose the court goes further and not only decides this case in a way involving a rule as to a state of facts, but lays down a principle, a starting point for legal reasoning. There is a case where the courts are supposed .... to exercise gentlemnanly restraint. You cannot frame a principle with any assurance on the basis of a single case.

29. Id.

30. Id. at 36 . 
It takes a long process of ... judicial inclusion and exclusion to justify you in being certain that you have hold of something so general, so universal, so capable of dealing with questions of that type that you can say here is an authoritative starting point for legal reasoning in all analogous cases. ${ }^{31}$

While Pound was commenting upon the growth of principles through judicial decisions, the process is generally not very different for principles derived from other sources. Morals, unlike laws, are not made, but rather grow, develop, and mature over time. Hence if we share with Dworkin the behef that a principle is "a standard that is to be observed, not because it will advance or secure an economic, political, or social situation deemed desirable, but because it is a requirement of justice or fairness or some other dimension of morality,"32 it becomes all the more clear why I urge that principles grow and hence, unlike rules, are not invalidated when they are destroyed. What, among other things, is mteresting about policies is that they, like rules, are typically made, but unlike rules are neither valid nor invalid; and although made, unlike principles, typically, like principles, they are not destroyed but rather eroded.

Dworkin draws attention to another interesting feature about policies when he advises that it is important to

distinguish between standards ( . . which entitle participants to inake claims as of right ...) and binding policies that are not standards. The general in war owes a duty to his nation to make decisions that he believes most advance the victory. Yet neither the nation nor any of his men nor the eneny can be said to be entitled as of right to any particular decision. The policy of victory does not also act as standard for determining claims, rights or entitlements. ${ }^{33}$

While there is something here that is interesting, I do not think it is quite the point Dworkin makes. While a binding policy may be relevant and still not be the basis for a claim or entitlement to a particular decision, if that policy is binding and relevant then it is the basis for the claim that certaim decisions will not be made. In other words, such policies do provide a source for standards-standards that circumscribe the range of possible, proper decisions, that is, decisions to which we are entitled. And this is so because typically, even less than principles, policies do not dictate results. Generally, such a wide range of decisions may be accommodatable within the range of decisions consistent with the policy that it is difficult, although not impossible, to show that we are entitled to have a particular decision. Thus, if the general de-

31. Pound, Survey of the Conference Problems, 14 U. CiN. L. REv. 323, 330

32. Dworkin, supra note 16 , at 14 .

33. Dworkin, supra note 22, at 633. 
cides to stop fighting, we needn't conclude that the nation has no greater claims upon him than if, for example, he decides to bomb target $A$ rather than $B$. To stop fighting is inconsistent with the binding pohicy. Victory as a policy is destroyed, not just weakened or eroded, unless we are to play games with the meaning of "victory."

Without going to the extreme of a general who engineers defeat rather than working for victory, why doesn't the binding policy furnish a standard for even less drastic decisions? Dworkin's formulation of what is here at stake is misleading because it confuses accountabihity with entitlement. If the general makes what the large consensus of knowledgeable people and professional military experts regards as a clearly bad decision, it seems sensible to say that the nation did not get the performance from him that they were entitled to expect. His decision in this instance was so bad that it was incompatible with his duty "to make decisions that he believes most advance the victory." Now it may be thought that the bad decision is compatible with this duty because the general did believe it would most advance the victory. But that is just the mistake referred to about confusing accountability and entitlement. If the general did believe im his decision and made it not because he was bribed, or drunk, or an enemy agent, he will be guilty of military incompetence, perhaps even of stupidity, but not of treason. His honest behef saves him from that when the question is accountability. But it does not destroy the quite proper sense in saying that his decision was incompatible with the binding, relevant policy and contrary to what we could properly, legitimately expect of one who undertakes to serve as general.

Compare the judge. Take a policy of sufficient generality, comparable to that of victory for the general, for example, that the judicial system not be uunecessarily weakened. If a judge makes a bad decision, one incompatible with that pohicy, and if, like the general, there is no further appeal from the decision of this judge, it makes good sense to say that his decision was not one of the several possible decisions that would have been compatible with the claim of the community. The pohicy does furnish some standard, but unlike rules, even if the policy apphes, it does not dictate a result. Sufficiently general policies (or principles, for that matter) always apply, both in making war and in making judicial decisions, but the very generahty that makes thein universally relevant also diminishes their utility as a source of standards to guide or incline the court to a particular decision; rather, they function to mark off the parameters within which more specific standards will lead to an acceptable decision. The incompetent judge, like the incompetent general, may avoid removal because it is generally recognized (or he shows) that his bad decision was neither contrary to the 
rules (for example, against taking bribes) nor contrary to important principles (for example, about impartiality); but this only shows that on the accountability issue (at least within the system) he prevails. The really hard case comes when the judge or general is to be removed from office not because of treason, bribery, or partiality, but just because of incompetence. This requires showing a kind of incompetence so extreme that honest betief is no defense to sanctions imposed within the system. Neither the general nor the judge may be imprisoned or shot for destroying or weakening the system by their honest incompetencebut they are not privileged to be that imcompetent. If they may be removed, it means that there are policies and principles that provide relevant standards within the system for ascertaining how incompetent one may be even if he is elected or appoimted to a public office.

\section{CONCLUSION}

Different sins may be hidden or uncovered in the search for the justification of a judicial decision. Even slightly unpacking the notion of justification reveals the need to differentiate (1) justification of a judicial decision and (2) justification of the rules, primciples, and policies relied upon to furnish dispositive standards. This latter feature is itself double lieaded, for there is a difference between (3) justification of the rules, principles, and policies themselves and (4) justification of the reliance placed upon them in a particular case. In this Article, I have suggested that while (1) and perhaps even (4) are largely determinable by considerations of the imstitutional design, (2) and (3) are not. Or, at least, questions about (2) and (3) do not readily lend themselves to disposition by reference to the expectations or entitlements that are ainong the consequences of the judge having agreed to resolve conflicts by the judicial method.

This Article has suggested that there is a fairly well entrenched inodel or design of the judicial method of conflict resolution from which standards may be derived for assessing judicial performance. Among these standards are some crucial ones relating to what the judge must account for in the way le decides a case. When he accounts for relevant rules, principles, and policies supported by prior cases, he is following the appropriate design, using the proper method-that is, the design or metlod that reflects, among other principles and policies, the one known as stare decisis. Because stare decisis dictates certain crucial features in the design of the judicial method, I have suggested that it is more helpful to look to the institutional design, rather than to logic or morals, for an explanation of what standing by precedent means. 